\title{
Reflections on the Relationship Between the Led and the Leader
}

\author{
Sydney Jary \\ $\mathrm{MC}$
}

\section{Kingston House, Odiham, Hants RG29 1LT}

Be kindly affectioned one to another with brotherly love; in honour preferring one another. (The Epistle of Paul the Apostle to the Romans Ch. 12 v10)

The usual approach to the subject is via the leader. The object of this paper is to do so via the led and, in doing so, to attempt to illustrate the basic requirement most of us have to serve under good leadership. I trust that it will dispel some common misapprehensions about the characteristics that make a good leader. Although written by a battle experienced infantry officer it is aimed to cover a wider application than the purely military.

One of the many factors that the medical and the military professions have in common is that they are equally lampooned by writers, particularly for films and television. Rarely has the ethos of two professions so cruelly been misrepresented.

In films and on television the type of man who makes a good leader now rarely appears. Forty years ago there were exceptions, mainly in some British films about WWII, where actors had personal war experience. I remember outstanding performances by Jack Hawkins - The Welch Regiment, Kenneth More - The Royal Navy, Richard Todd - KOYLI and The Parachute Regiment and others. Such, accurate character portrayals are now, particularly on television, almost extinct. I now avoid war films and, except in the case of 'Private Ryan', which I was literally ordered to see, my personal ban has lasted for thirty years. Apart from the first twenty minutes, 'Private Ryan' proves my contention. The characters were not soldiers but an undisciplined rabble who certainly would not have survived ten minutes in the Normandy bocage. Their officer had no qualities of leadership and, had one of my soldiers shot a prisoner, as one did in the film, he would undoubtedly have been sent for court martial. To me it was all pure Hollywood fantasy liberally applied with tomato sauce.

The impression that films and television now present is a pity because it ignores, and in some cases denigrates, the sort of men who literally won the war. The fact is that infantry soldiers will not follow a leader who has the characteristics of some of the parts played by John Wayne and other of that ilk. They see the 'macho' officer as a threat to their very lives; who will get them killed in, at the best, an ill-conceived operation or, at the worst, in an exhibitionist display of personal valour.

I also suspect that in the medical profession your patients would have reservations about the advice given to them by Sir Lancelot Spratt but, one must admit that the 'Doctor' series was certainly not remotely meant to be taken seriously.

Now let us examine the qualities that give soldiers confidence in their leader some of which, are usually considered to be feminine ones.

\section{Firstly Patience,}

the product of character, giving a quiet mind, at peace with itself. Charisma or a forceful personality are rarely adequate at the 'sharp end'. Patience encourages a reasoned appreciation of the 'factors effecting' when making a plan. It also impresses those to whom the resultant orders are given: 'this chap knows his stuff and doesn't get rattled'. If things go wrong, as they invariably will do, the same patient relaxed mind will unravel the unforeseen problems. ("No battle plan survives five minutes close contact'; von Moltke). All infantry soldiers ask themselves, "will this officer win battles and do his best to keep me alive'.

Secondly Grip,

which is acquired by the exercise of the qualities explained in Patience (above) and also the trust earned by an officer's personal integrity. ('Always choose gentlemen for your officers'; George Washington). Grip on oneself, Grip on one's soldiers and Grip on the situation. The Grip of the leader on the led is paramount. Nowhere is this more important than in the platoon or company battle. It is decisive because if you do not dominate events your enemy will. Monty always maintained that 'you keep the enemy dancing to your tune'.

Thirdly Sufferance,

without which you could not survive. The Army tends to use Fortitude in the same context. I prefer the former because it does convey one's inability to kick against many of the pricks. It breeds compassion for your own soldiers, prisoners and civilians caught in the conflict.

Fourthly a Sense of the Ridiculous,

improves relationship with all sorts of men and women and also keeps your relationship to 'the war, the whole bloody war', (Captain Ericson in 'The Cruel Sea') within some tolerable perspective.

Let us now examine what wins battles. Firstly, leadership and morale, the former develops the latter. Sound leadership - like love to which I suspect it is closely related - is all powerful. It can overcome the seemingly impossible and its effect on both leader and led is profound and lasting. It is, in effect, an exercise in unselfishness. "Serve to lead" is the motto of the Royal Military Academy Sandhurst (RMAS). Never was there a better one.

Secondly, Training which in practice is the finest welfare you can give to your soldiers. It irons out, in rehearsal, many of the problems that can arise in battle, but not all of them. Conductors of symphony orchestras confirm that good performances are born in rehearsal where a sound professional grounding gets the orchestra on the correct track. In performance the conductor's leadership takes over thus extracting the benefits of rehearsal to produce a fine performance.

Thirdly the learning curve of Experience from which sensible leaders and the led discover what they can do and, more importantly, what they cannot do. In my day it was known as 'knowing the form' - a horse racing term.

And lastly, the method in which the company, battalion, brigade and division is committed to a battle. In short, good professional command and meticulous A \& Q staff work, G1 and G4. This includes good food, prompt delivery of post from home, every assistance to keep clean and fast and efficient CASEVAC. In my war the British Army fed well - superlatively well compared with any other army. Each day one hot meal was 
provided, except under unusually difficult circumstances. We were the envy of all other armies, particularly the US Army, who seized every opportunity to feed with us. I understand that this excellent tradition persists. Our mobile bath units kept us as clean as could be expected and also provided a laundry service. A hot shower, clean shirt, underwear and socks do much for morale. Soldiers are comforted by confidence in humane and efficient medical back up from stretcher-bearers trailing behind forward attacking companies - we had anything between two and ten stretcher-bearers, according to circumstances - to an RAP run by a respected RMO, with a good padre in attendance, and Field Hospitals with surgical teams as close as possible to the battle.

Much can be done to support four of the above factors but I am mainly concerned with 1, Leadership and Morale, which brings us into the realms of inspiration and some vital intangibles.

The most important emotional factor to guard against is that icy feeling in the soldier's heart and stomach that he is on his own, caught in a vast Kafka-like nightmare propelling him remorselessly into Dante's inferno. Relatives have told me that many soldiers in the First World War felt utterly without hope in that vulnerable condition. To counter this hopeless fear of the unknown, we turn to the homely and the familiar. We must be sure that our riflemen go into battle comforted by the familiar: their mates, a platoon commander they know and trust and who understands them, all within the womb-like security of their family, the Regiment.

Doug Proctor, who was one of my Section Commanders in 18 Platoon 4th Bn The Somerset Light Infantry, admirably sums up the matter as follows:-

"During my six years army service I knew many Officers some good - some bad. The most obvious difference between them was not in their tactical awareness as one might expect, but in the relationships they had with their soldiers. No matter how tactically aware an Officer may be, it counts for little unless he can command the trust, loyalty and respect of his men and is able to inspire them. The good Officers, without exception, enjoyed that trust, loyalty and respect.

In the Army of today weapons may have become more sophisticated and tactics more involved, but the qualities that are necessary in a good officer remain unchanged - he is a leader of men and should have the trust and respect of those he leads, but unfortunately this is not always the case, and although in peacetime the consequences of this are not so damaging, in times of war the effect can be disastrous.

A newly commissioned Officer commences his practical training in how to use and apply his power of command the moment he joins his Regiment and is appointed to his first platoon. The realities and problems of leadership then come to the forefront with startling clarity - especially if war time conditions exist. He must approach his first command with an open and receptive mind, with the aim of gaining the respect and confidence of those he leads and as a first step towards this end, has to show that he himself is sincere and caring and respects the men under his command. Some Officers no doubt expect trust and respect to be theirs by right, and fail to realise that these two essential factors in the relationship between officers and men are not cheaply or easily given but must be worked for and earned.

The Platoon should be thought of as a family, and the Officer at its head should not insulate himself against the demands emotional or otherwise - 'his family' will make upon him. He should give them his time and his friendship, and show a genuine interest in his men as individuals with their many and varied problems. Friendship for his men does not mean an end to discipline, as trust and respect imposes its own self discipline and he will find that the courtesies of rank will always be observed. Friendship is not to be confused with familiarity. The wise officer will listen to and learn about his platoon from his senior NCO's whose help and loyalty is to be highly valued, and will be freely given if approached without arrogance or patronage.

He should foster within his Platoon a spirit of friendly competition, and whenever possible join in and compete on equal terms with and against his men. Beating him will be the aim of them all and will engender within the Platoon a wonderful spirit of competitiveness and togetherness. Being beaten - as he surely will be - should be accepted with good grace and a sense of humour.

The young Officer must be scrupulously fair in all things, and must let it be seen that he is fair-double standards in his conduct towards his men must be avoided at all costs.

Tactics can only be truly learned by actually experiencing battle conditions, but in training the Officer must always take the lead, demonstrating that he is asking nothing of his men that he cannot do himself.

When things go wrong, a cool, level-headed, common sense appraisal of the situation is essential - a good Officer will never 'flap' or show indecision. In this way, trust and respect is cemented.

To summarise: A good Officer will command trust, loyalty and respect by:

Being sincere and caring.

Being a good listener.

Giving his time and friendship.

Showing genuine interest in his men as individuals.

Competing with and against his men.

Having a sense of humour.

Being scrupulously fair.

Leading from the front by example.

Being calm, level-headed, with good common sense.

Never showing indecisiveness."

Over the last few years there has been much written about the emotional and psychological problems arising from battlefield experience. I have reservations regarding my competence even to comment on the subject because none of my men suffered from them.

Admittedly one of our lance corporals had to be evacuated for about forty eight hours suffering from what in WWI would have been diagnosed as Shell Shock. In his case we all, including our excellent MO, considered it was caused by exhaustion and over exposure to high explosives. The condition manifested itself during the attack on Xanten, on the Rhine on 8th March 1945. We were shelled by German 105s and many of the projectiles had fallen on the road. A more lethal spread of splinters and much more noise occurs when shells land on a hard surface. It is most unpleasant. This NCO had served with honour since Market Garden in September 1944 and two days of good food and plenty of sleep closed the episode. This crude treatment, within the family, worked well and, I understand, coincides with current thoughts on the problem. Apart from this example of battlefield exhaustion, none of my NCOs or soldiers suffered from psychological or emotional problems; nor have they done so since.

Colonel Roger May MC, a fellow platoon commander who served with me in 4th Bn The Somerset Light Infantry, is firmly of the opinion that good leadership protects one's soldiers from these traumas. I agree with him but, for obvious reasons, I am reluctant to develop this theory any further.

Can leaders be made or are they born?

For a very few men and women some of the qualities, like patience and unselfishness, develop in their early years. Others, like grip, come later and that side of leadership can be developed as it is done, most effectively, at RMAS. 
There seems to me that there are two types of leaders. Firstly, the instinctive leader whom others immediately respect and trust and consequently will follow. They are the very few that we regard as born leaders. Secondly there are those who have to be brought out by wise and careful selection and training. Providing they maintain high standards of personal integrity and apply themselves conscientiously to their responsibilities others will follow them. For them the role of leader has to be worked for. For the born leader it comes easily and those few are indeed blessed, and are unlikely to understand why they are born leaders.

For many years, until quite recently, I was confident that the present generation of junior ranks would react to the trauma of the battlefield in the same way that my soldiers did. Recent experience has given me some doubts on this subject. It does seem to this old soldier that where the standard of officers and NCOs has not fallen - at some levels there seems to be in improvement - many of the most Junior ranks compare unfavourably with my excellent "hostilities only" soldiers.

Why may this be so? One wonders if the Welfare State is a poor breeding ground for self-reliant and independent minded young men. I do not include young women because there does not seem to be a similar decline of quality. There are also the changes in attitudes to service versus the rights of the individual. Does this lead to frivolous litigation concerning the emotional or psychological consequences arising from comparatively brief battlefield experience?

Perhaps I am being unfair to our Welfare State. Possibly this change in attitudes arises from one of those sea changes in the way life is ordered that we, and incidentally historians, often fail to understand. "Times change and we change with them" Seems to have overlooked most of our officers and NCOs. I wonder if it has also overlooked most doctors and nurses?

Let us now leave the service ethos, where leadership is appreciated and expected of those in authority.

I went into business where I found an almost total absence of leadership qualities. There were only two exceptions, one a retired Brigadier REME, the other a Swiss machine tool manufacturer.

To succeed in business other characteristics - I will not dignify by calling them qualities - are required. To succeed you require energy, ambition, enthusiasm, plausibility and a degree of intolerant ruthlessness. A cocktail of egocentric characteristics which hardly inspires the trust of subordinates. It does, however, gain the confidence of clients. It sells.

I ran my own publishing company for almost forty years by the standards of leadership we take for granted in the services. Few staff problems arose and certainly none from the heavily unionised shop floor staff at our printers. I brought energy and enthusiasm but not plausibility and ruthlessness. I must admit that I also lacked real ambition; but I was enterprising. The result: I earned an adequate living but the company did not develop in the way it would have done in the hands of a real businessman.

I would suggest that most companies require two chief executives; a "peoples" Chairman responsible for the staff and a development Chairman to make deals and to develop the commercial side. Few, if any executives, possess the characteristics to perform both functions.

I appreciate that in peacetime the services can be frustrating, particularly to the imaginative and innovative leader. However experience suggests to me that he should stick to his last. Venturing into activities where the spirit of service is not paramount can be as uncomfortable as it is unrewarding. In those areas independence of mind, candour with superiors and even integrity are largely unwelcome.

May I leave you with this thought? Many years ago a much loved relative of my late wife said to me, "you know Sydney I can actually lead some of my patients out of their illness". Uncle Reg, Dr Faux, was Gynaecological Consultant, for many years, at Bolton Infirmary. He also found the time to be a much respected GP. 